\title{
Soubor štípané industrie časného a staršího eneolitu ze sídliště Rousínovec - Přední lány
}

\section{Collection of Early and Old Eneolithic chipped stone industry from the settlement of Rousínovec - Přední lány}

\section{Ludmila Hladíková-Kaňáková}

\begin{abstract}
Abstrakt
Štípaná industrie časného a staršího eneolitu je dosud jen málo známa z publikovaných zdrojů. I šiřeji, mezi štípanou industrií lengyelské kultury a štípanou industrií kultury se zvoncovitými poháry zůstává dosud značná publikační rezerva, ačkoli jednotlivosti jsou v posledních letech pozvolna publikovány a velký potenciál k dalšímu poznání skýtají některé dosud neanalyzované početné sběrové kolekce. Soubor získaný při záchranném archeologickém výzkumu roku 2006 je zvláště cenný s ohledem na distribuční a technologické informace, které poskytuje pro dosud skrovně objasněné okolnosti výroby a používání Šı ve starším eneolitu.
\end{abstract}

\section{Klíčová slova}

Jordanovská kultura, kultura nálevkovitých pohárů, sídliště, štípaná industrie, lokální rohovce

\begin{abstract}
For the time being, Early and Old Eneolithic chipped stone industry is little known from published sources. Also in a wider context, a considerable publishing gap still exists between chipped stone industry of the Lengyel Culture and of the Bell Beaker Culture, even though individual details have gradually been published in the past few years and some of the numerous still unanalysed surface collections offer a high potential for further knowledge. The assemblage acquired during an archaeological rescue excavation in 2006 is particularly valuable with regard to distributional and technological information which can elucidate in detail the still incompletely explained production and usage of chipped stone industry in the Early and Old Eneolithic.
\end{abstract}

\section{Keywords}

Jordanów Culture, Funnel Beaker Culture, settlement, chipped stone industry, local cherts

Studie byla podpořena specifickým výzkumem MUNI/A/0734/2017, Archeologická terénní prospekce, exkavace, dokumentace a muzejní prezentace VII. 


\section{1. Úvod}

Hodnocený soubor pochází ze záchranného archeologického výzkumu ÚAPP Brno, pobočka Vyškov. Na mírném svahu trati Přední lány v katastru obce Rousínovec (poloha lokality viz obrázek 1) se nacházelo sídliště jordanovské kultury a další část již dřive zkoumaného sídliště kultury nálevkovitých pohárů (Čižmár - Geisler - Horálková 1986).

Roku 2009 výzkum pokračoval odkrytím dalších celkem 22 sídlištních objektů řazených na základě nálezů keramiky ke kultuře nálevkovitých pohárů (Mikulková 2010, 337). Nálezy z obou těchto výzkumů nebylo možné k analýze získat s ohledem na badatelský zájem jiných osob.

Dosavadní poznatky o štípané industrii (dále ŠI) jordanovské kultury (dále JoK) vychází pouze z předpokládané tradice epilengyelského komplexu. Štípané industrii kultury nálevkovitých pohárů (dále KNP) byla dosud v moravském badatelském prostředí věnována pozornost zejména $\mathrm{v}$ souvislosti s atraktivními nálezy, at již šlo o depot dlouhých čepelí na Stránské skále (Svoboda - Šmíd 1996), nebo charakteristické tvary projektilů (Bř́za - Ulahel 2015, 74; Šikulová - Zápotocký 2010, 407). V posledních letech jsou sice publikovány soubory z výšinných sídlišt na střední Moravě (Šmíd Dreslerová - Přichystal 2010, 107-109; Šmíd Přichystal 2015, 146-148), není však prováděna žádná analýza těchto souborů. V oblasti Čech jsou soubory ze sídlišt KNP publikovány rovněž jen z několika sídlištních lokalit (Vencl 1985; Vencl 2012; Vencl 2014), poskytují však cenné informace o charakteru distribuce surovin, spektru kolekce z hlediska dynamické analýzy a rámcovém intrasite rozložení ŠI. V analýzách souborů ŠI KNP z oblastí severněji od našeho území jsou kromě projektilů (Iversen 2014, 48-51) výrazněji akcentovány také laterální drobně zoubkované retuše - microdenticulates
(Högberg 2016; van Gijn 2010) nebo škrabadla a příčné retuše (Domańska 2013).

Již v úvodu je třeba říci, že soubor z Rousínovce všechny tyto atraktivní artefakty postrádá, přesto skýtá řadu zejména technologických informací.

\section{Nálezové okolnosti}

Vzhledem k tomu, že se jedná o lokalitu se sídlišti dvou chronologicky značně blízkých kultur, je otázka kulturní příslušnosti výplně objektů poměrně ožehavá. Tento článek si nečiní ambice řešit složité depoziční a postdepoziční okolnosti archeologie sídlišt, pouze přispívá analýzou ŠI k možnostem jejich analýzy na konkrétním sídlišti se dvěma fázemi osídlení.

Při analýze souboru byl brán v úvahu nejen zjištěný datovatelný (dle nálezové zprávy byla využita pouze keramika) materiál, ale i funkce objektu ve vztahu k procesům spojeným se ŠI. Plán odkryté plochy z roku 2006 (obrázek 2) barevně odlišuje objekty datované na základě typologie keramických nálezů do rámce jordanovské kultury nebo kultury nálevkovitých pohárů. Přehledně jsou objekty s obsahem ŠI popsány v tabulce č. 1 .

Jak si lze povšimnout, ŠI se nikdy nevyskytuje v zásobních jamách KNP (a v jamách bez datovaného materiálu), ale vyskytuje se ve všech zásobních jamách jordanovské kultury. Z hlediska funkce není pro intaktní přítomnost ŠI v zásobních objektech důvod, a ani její určení tomu nenasvědčuje. Vyskytují se v nich zejména jádra (a další artefakty spojené s výrobou ŠI - otloukač, dekortikační debitáž) a zlomky nástrojů a debitáže. Již na základě těchto dat se lze tedy domnívat, že do zásobních jam jordanovské kultury se ŠI dostala sekundárně, nejspíše tedy v průběhu osídlení plochy v období KNP, ačkoli bychom mohli zvážit i hypotetickou možnost opuštění některých zásobních jam již v průbě- 

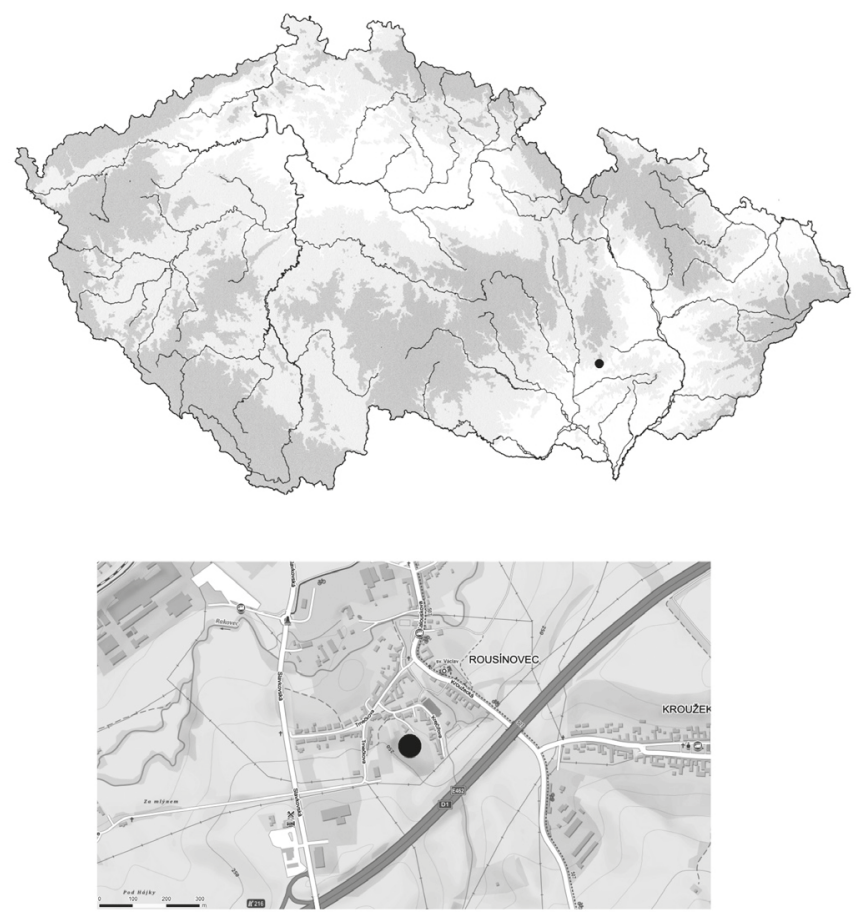

Obr. 1. Přehledová mapa České Republiky s lokalizací naleziště.

Fig. 1. An overview map of the Czech Republic with localisation of the site.

hu jordanovského osídlení. Výskyt ŠI v běžných sídlištních jamách a v hlinících již nelze na základě funkce takto přesvědčivě spojit $\mathrm{s}$ jedním ze dvou horizontů osídlení plochy. K jejich náhodnému zaplňování sídlištním odpadem pravděpodobně docházelo již v průběhu osídlení, nikoli až po zániku horizontu, jako v případě zásobních jam, kde můžeme předpokládat, že jsou po dobu užívání udržovány v čistotě. V případě sídlištních jam a hliníků bez precizního mikromorfologického výzkumu (který obvykle není možný v podmínkách záchranného výzkumu) spolehlivého odlišení depozičních fází nelze dosáhnout.

Podobně sídlištní jámy KNP, v nichž se vyskytuje ŠI, mohly být ve skutečnosti sídlištní jámy JoK s jejich funkčně příslušnou ŠI, do nichž mohla být druhotně nanesena již fragmentární keramika KNP.
Navzdory nezbytné obezřelosti ve spoléhání na dataci na základě výplně sídlištních objektů se zdá, že oba areály se respektují, s převahou objektů KNP severněji a převahou objektů JoK ve střední části kolem nadzemního domu a v jižní části exkavované plochy, kde se nachází další stavební jámy - hliníky. Podle nálezové zprávy (Mikulková 2006, 57-58) jsou objekty 535 a 536 rozdělující pomyslně jordanovskou zónu, datovány na základě keramiky do období KNP jen pravděpodobně (uvedeno s otazníkem, obsah keramiky byl spíše stopový).

\section{Analýza}

Soubor štípané industrie z výzkumu roku 2006, který byl dostupný k základní analýze, čítá celkem 55 artefaktů ze čtrnácti objektů. Je v zásadě 


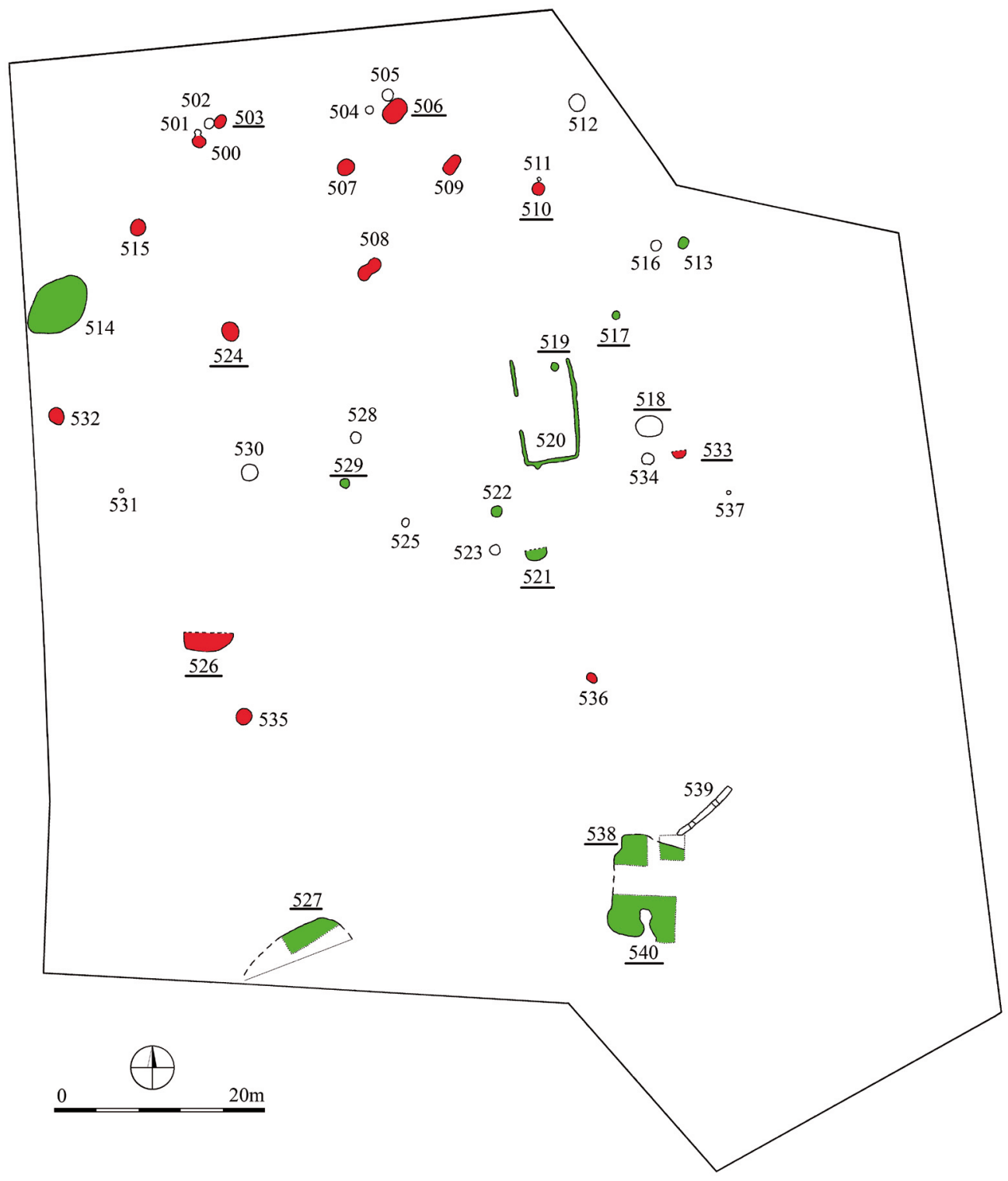

Obr. 2. Plán výzkumu z roku 2006 (upraveno na základě Mikulková 2006, plán 1). Zeleně jsou vyznačeny objekty datované dle keramiky do jordanovské kultury, červeně do kultury s nálevkovitými poháry. Objekty bez barevného značení nebyly na základě nálezů datovány nebo byly bez nálezů. Objekty, jejichž číslo je podtrženo, obsahovaly Šı.

Fig. 2. Plan of excavations in 2006 (edited after Mikulková 2006, plan 1). Archaeological features assigned on grounds of pottery to Jordanów Culture are marked in green, features of the Funnel Beaker Culture are marked in red. Features without colour marking were either not dated on the basis of finds or they did not contain any finds at all. Features with underlined number contained chipped stone industry. 


\begin{tabular}{|c|c|c|c|c|c|}
\hline & & & kce objektu & & \\
\hline & keramiky & $\begin{array}{c}\text { sídlištní jáma } \\
\text { nezjištěné funkce }\end{array}$ & zásobní jáma & $\begin{array}{l}\text { jáma rámcově } \\
\text { stavební funkce }\end{array}$ & ŠI \\
\hline objekt 500 & KNP & + & & & \\
\hline objekt 501 & nedatovaná & + & & & \\
\hline objekt 502 & nedatovaná & + & & & \\
\hline objekt 503 & KNP & + & & & + \\
\hline objekt 504 & nedatovaná & + & & & \\
\hline objekt 505 & nedatovaná & + & & & \\
\hline objekt 506 & KNP & + & & & + \\
\hline objekt 507 & KNP & & + & & \\
\hline objekt 508 & KNP & + & & & \\
\hline objekt 509 & KNP & + & & & \\
\hline objekt 510 & KNP & + & & & + \\
\hline objekt 511 & nedatovaná & & & + (kůlová jáma) & \\
\hline objekt 512 & nedatovaná & + & & & \\
\hline objekt 513 & JoK & + & & & \\
\hline objekt 514 & JoK & & & + (hliník) & \\
\hline objekt 515 & KNP & & + & & \\
\hline objekt 516 & nedatovaná & + & & & \\
\hline objekt 517 & JoK & & + & & + \\
\hline objekt 518 & eneolit & + & & & + \\
\hline objekt 519 & JoK & & + & & + \\
\hline objekt 520 & JoK & & & + (žlábek) & \\
\hline objekt 521 & JoK & + & & & + \\
\hline objekt 522 & JoK & + & & & \\
\hline objekt 523 & nedatovaná & & + & & \\
\hline objekt 524 & KNP & + & & & + \\
\hline objekt 525 & nedatovaná & & + & & \\
\hline objekt 526 & KNP & + & & & + \\
\hline objekt 527 & JoK & & & + (hliník) & + \\
\hline objekt 528 & nedatovaná & & + & & \\
\hline objekt 529 & JoK & & + & & + \\
\hline objekt 530 & nedatovaná & + & & & \\
\hline objekt 531 & nedatovaná & & & + (kůlová jáma) & \\
\hline objekt 532 & KNP & + & & & \\
\hline objekt 533 & KNP & + & & & + \\
\hline objekt 534 & eneolit & + & & & \\
\hline
\end{tabular}




\begin{tabular}{|c|c|c|c|c|c|}
\hline & \multirow{2}{*}{$\begin{array}{l}\text { datace dle } \\
\text { keramiky }\end{array}$} & \multicolumn{3}{|c|}{ funkce objektu } & \multirow[b]{2}{*}{ Šı } \\
\hline & & $\begin{array}{c}\text { sídlištní jáma } \\
\text { nezjištěné funkce }\end{array}$ & zásobní jáma & $\begin{array}{l}\text { jáma rámcově } \\
\text { stavební funkce }\end{array}$ & \\
\hline objekt 535 & KNP? & + & & & \\
\hline objekt 536 & KNP? & & + & & \\
\hline objekt 537 & nedatovaná & & & + (kůlová jáma) & \\
\hline objekt 538 & JoK & & & + (hliník) & + \\
\hline objekt 539 & nedatovaná & & & + (žlábek) & \\
\hline objekt 540 & JoK & + & & & + \\
\hline
\end{tabular}

Tab. 1. Přehled výskytu Šı v objektech odkrytých výzkumem roku 2006.

Tab. 1. An overview of distribution of chipped stone industry in features excavated in 2006.

homogenní po surovinové i technologické stránce, s výjimkou patinovaného artefaktu z objektu 503 , který byl vyloučen jako pravděpodobná intruze. Bud' jej lze tedy přičíst celý jedné z prrítomných kultur, nebo je nutné konstatovat, že ŠI obou kultur se nijak zásadně neliší, zvláště nejsou-li přítomné výraznější kulturní indikátory zmíněné výše. ${ }^{1}$

Dominantní surovinou souboru jsou pestré variety rohovců ze Stránské skály (41ks, $75 \%$ ). Variety definoval již v roce 1982 A. Přichystal (přehledně shrnuty jsou v práci Přichystal 2009, 65 a 67 , a foto 47 na s. 274). Z hlediska tohoto třídění lze konstatovat, že se nevyskytly variety E, F, H a I, objevily se však variety, které nelze vždy spolehlivě spojit s ostatními takto definovanými varietami. Protože archeologové obvykle pracují s makroskopickým určováním, pro detailnější třídění souboru dle suroviny používám kombinaci škály barevnosti a škály kvality (Hladiková 2004, 69). Přehledně jsou zjištěné variety uvedeny v grafu na obrázku č. 3. Nejvýrazněji je zastoupena matně šedivá varieta bez páskování, neprůsvitná, se světlou kůrou, ostře drsná v haptickém dojmu (37\% v rámci artefaktů z tohoto rohovce), kterou lze ztotožnit $\mathrm{s}$ varietou A dle Přichystala. Až na výjimky (1ks) ji lze v kvalitativní škále definovat jako hmotu kvalitní. Naopak častěji jemnou kvalitu má varieta, která se jevila nápadně světlejší, stále v šedé barvě (24 \% v rámci variet rohovce Stránské skály). Vyskytly se nicméně i tóny šedohnědé a světle hnědé, u nichž byla hmota také častěji charakterizována jako jemná (27 \% v rámci variet rohovce Stránské skály). Poslední zastoupenou varietou je zonální surovina, dle Přichystala definovaná jako varieta B (12\%). Ačkoli v popisu z poslední syntézy není varieta se světle hnědými tóny (viz obrázek č. 4) popsána, dle pers. comm. A. Přichystala jde právě o varietu preferovanou v souborech KNP na Stránské skále.

Vzdálenost Stránské skály vzdušnou čarou není velká, cca $15 \mathrm{~km}$. V souboru se však v menšině objevují i suroviny ze vzdálenějších zdrojů. Obě variety rohovce typu Krumlovský les (3 ks, $5 \%$ ) mohou pocházet nejen z eponymní oblasti Krumlovského lesa, kde je nově publikována těžební aktivita i v období KNP (Oliva 2017), ale hypoteticky mohou rovněž pocházet ze Stránské skály a jejího severovýchodního okolí (Přichystal 2009, 72). Zajímavější je již výskyt silicitů ze severnějších oblastí. Z hlediska makroskopického určení je společně uvádím jako silicit glacigenních sedimentů (SGS) s tím, že některé kusy s ohledem na svou výrazně tmavší ořechově hnědou barvu mohou původně pocházet z krakovsko-čenstochovské jury (A74692, A75513, A75601). Na výskyt této suroviny (dále KČJ) 




Obr. 3. Graf výskytu surovin a jejich variet, v přehledu zastoupení kvalitativní škály hmot.

Fig. 3. Graphic representation of the occurrence of raw materials and their varieties, an overview of the quality spectrum of materials.

i v glacigenních sedimentech až po Ostravsko však upozornil A. Přichystal (Přichystal 2009, 48), je tedy důležité brát tento jev v úvahu v př́ipadných distribučních modelech. Vzdálenost těchto zdrojů je od lokality vzdušnou čarou cca 120 až $140 \mathrm{~km}$.

Na základě dat z nálezové zprávy byla sledována distribuce jednotlivých variet rohovce typu Stránská skála a dalších surovin v rámci objektů i v rámci zkoumané plochy, zejména s ohledem na typologickou dataci objektů (graf viz obrázek č. 5), a dále na plošnou distribuci, zejména $\mathrm{s}$ v souvislosti s výskytem jader.
Z grafu je patrný jistý rozdíl mezi ŠI objektů připisovaných JoK a KNP. ŠI připisovaná typologií keramiky v objektech jordanovské kultuře se výrazněji přiklání k jemným hmotám, jak z hlediska výběru variet a surovin, které častěji mají jemnou hmotu, tak z hlediska počtu artefaktů jemných hmot např́íc surovinami a varietami. To je důležité rozlišit, protože i suroviny, jejichž hmotu považujeme za homogenní v tzv. pazourkové kvalitě, se vyskytují v různých hrubostech hmoty a naopak. V případě souboru ŠI připisované JoK však sledujeme př́klon k jemným hmotám v obou př́stupech. Také pouze v této 
A
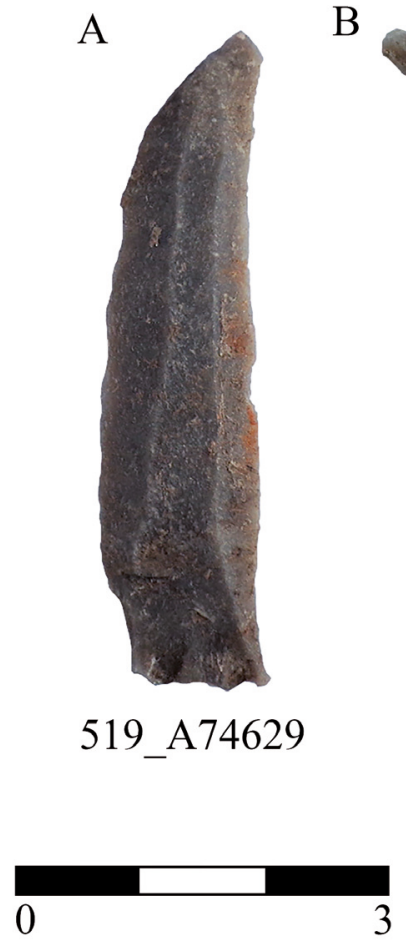

B

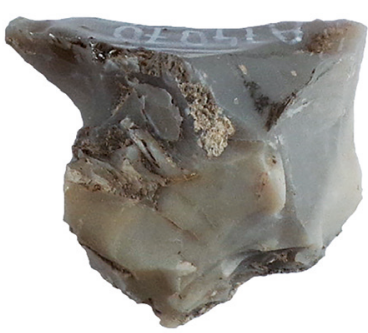

510_A74070
$\mathrm{C}$

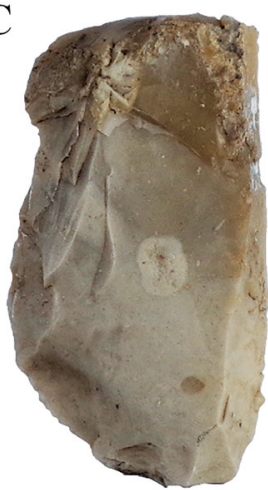

$\mathrm{D}$

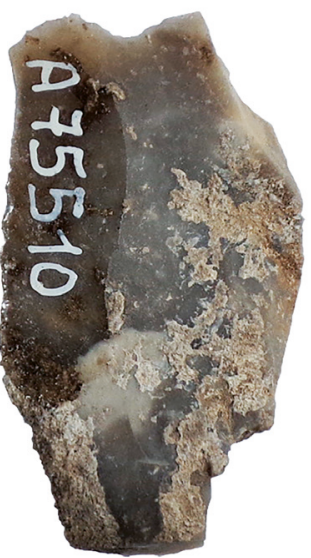

538 A 78810

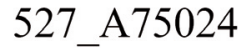

$\mathrm{E}$

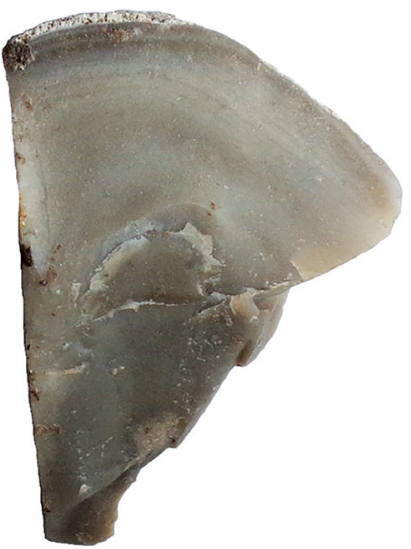

524_A74766

Obr. 4. Porovnání zjištěných barevných variet rohovce typu Stránská skála. A. varieta šedivá (varieta A dle Přichystala), B. varieta světlá, C. varieta světle hnědá, D. varieta šedohnědá, E. varieta zonální (varieta B dle Přichystala).

Fig. 4. Comparison of detected colour varieties of the Stránská skála chert. A. grey variety (variety A after Přichystal), B. pale variety, C. light brown variety, D. grey-brown variety, E. zonal variety (variety B after Prichystal).

části sledovaného souboru se vyskytuje rohovec Krumlovského lesa I a II (dále KL I a KL II) a světle hnědá varieta rohovce Stránské skály. Naopak drsná šedivá varieta tohoto rohovce je zastoupena méně.

Pokud bychom relativizovali kulturní příslušnost ŠI nalezené v zásobních jamách JoK, což jsou objekty č. 517, 519 a 529, pak by se tento obraz ještě více zvýraznil. Jednotlivé výskyty zonální variety rohovce Stránské skály a rohovec KL I kvalitní hmoty by se přesunuly do kontextu KNP, který ke kvalitním hmotám tenduje výrazněji (obrázek č. 6).

Z hlediska distribuce jednotlivých variet a surovin v rámci odkryté plochy (obrázky č. 7 až 13) lze sledovat, že zatímco v severní zóně síd- 




Obr. 5. Graf distribuce surovin a variet v objektech podle datace založené na typologii keramiky.

Fig. 5. Graph of distribution of raw materials in individual features according to dating based on ceramic typology.

liště, která by měla souviset s osídlením KNP, převažují suroviny kvalitní hmoty, především variety rohovce Stránské skály šedivá, světlá a zonální, zatímco ve střední a jižní zóně, spíše jordanovské, se vyskytují suroviny jemné hmoty, zahrnuje všechny výskyty SGS/KČJ, KL II a šedohnědé variety rohovce Stránské skály. Opět $\mathrm{v}$ tomto případě při relativizaci kulturní příslušnosti ŠI v zásobnicích s doklady keramiky JoK, tento obraz se ještě zdůrazní.

Pokud se na sídlišsti nachází jádra, je důležité rovněž provést základní ověření možnosti identifikovat výrobní zóny nebo objekty. Proto jsou na výše zmíněných obrázcích 7 až 13 jádra každé suroviny vizualizována jako velký křižek na rozdíl od ostatní ŠI, která je vyznačena malým křížkem. Z této analýzy dobře vyplývá, že depozice ŠI v zásobních objektech JoK není kulturně a funkčně původní, ale došlo k ní ná- hodnými procesy. V objektu č. 517 se nachází jádro a otloukač ze šedivé variety, jádro ze světle hnědé a jádro ze zonální variety. Žádný z dalších artefaktů v objektu není vyroben z těchto surovin, všechny jsou z variety světlé. V objektu č. 519 se nachází jádro z KL I, ale debitáž zahrnuje variety rohovce Stránské skály - slabě zonální, šedivou a jeden artefakt přepálený. V objektu č. 529 se nacházel pouze zlomek úštěpu šedivé variety rohovce Stránské skály. Surovina jader tedy není v souladu se surovinou debitáže v objektu. Jádra se dostala do objektu stejně náhodně jako ostatní debitáž a nejsou dokladem výrobní zóny. Naopak, u sídlištní jámy KNP č. 524 můžeme takovou souvislost jádra a debitáže identifikovat. Ačkoli vyznačené jádro variety šedivé (obrázek č. 7) je pouhým zlomkem špičkou jádra, výrobní aktivitu dokládá charakter dalších artefaktů ze stejné suroviny. Jedná 




Obr. 6. Graf distribuce surovin a variet v objektech podle datace založené na typologii keramiky po revizi datace Šl ze zásobních objektů jordanovské kultury.

Fig. 6. Graph of distribution of raw materials and varieties in individual features according to dating based on ceramic typology after a revision of dating of chipped stone industry from storage features of the Jordanów Culture.

se o tři produkty dekortikace jádra (kortikální úštěp, kortikální zlomek suroviny a úštěp s kortikálním bokem a terminální částí), reparační úštěp a zlomek úštěpu bez kůry. Také situace v jordanovském hliníku č. 538, částečně superponovanému jordanovskou jámou č. 540 svědčí o výrobní zóně. Distribuce SGS (obrázek č. 13) vychází z objektu č. 538, kde je doloženo jak jádro, tak neretušovaná debitáž. Naopak retušovaná debitáž z této suroviny se vyskytuje v sídlištních jamách v okolí - dvě čepele $\mathrm{s}$ vruby (objekty č. 521 a 526) a škrabadlo (objekt č. 533). V objektu č. 538 se také vyskytlo jádro variety šedohnědé, jejíž debitáž se nachází jen na místě a v nepř́liš vzdáleném objektu č. 527 (obrázek č. 10).
Z hlediska základní dynamické analýzy se v souboru ve zvýšené míře vyskytují jádra a další průvodní dílenský inventář, jako zlomky suroviny, otloukač a reparační úštěpy. Debitáž s podílem kưry je s ohledem na počet jader v menšině, takže lze předpokládat, že větší část prvotní dekortikace hlíz probíhala jinde, nebo nebyla tato pracovní zóna rozsahem výzkumu zachycena. Neretušovaná debitáž neodpovídá většinově charakteru jader. $Z$ toho je možné soudit, že většina cílových produktů těžby přítomných jader se v odkryté zóně sídliště nenachází a byla distribuována jinam. Všechny tyto projevy dokládají dílenský, zpracovatelský, a zároveň maximálně vytříděný, až odpadní charakter souboru. Jádra se koncentrují v objektu 


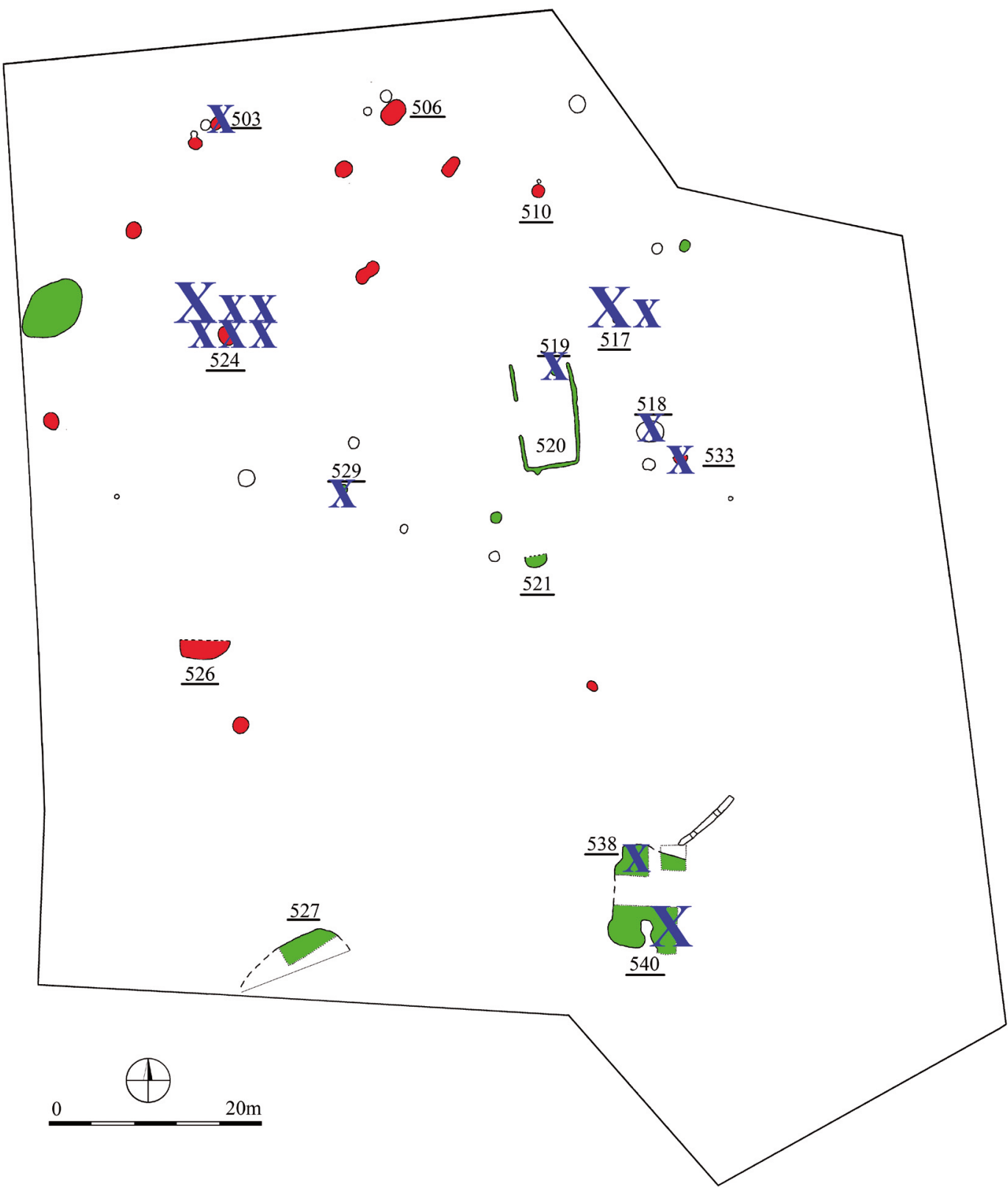

Obr. 7. Distribuce rohovce Stránské skály - varieta šedivá v objektech exkavované plochy. Zeleně - objekty datované na základě typologie keramiky do JoK, červená - objekty datované na základě typologie keramiky do KNP, modrá - výskyt jedinců (velký křížek - jádro nebo jeho zlomek, malý křížek - ostatní Šl).

Fig. 7. Distribution of Stránská skála chert - grey variety in features within the excavated area. Green - features assigned on the basis of ceramic typology to the Jordanów Culture, red - features assigned on the basis of ceramic typology to the Funnel Beaker Culture, blue - individual occurrence (large cross - core or core fragment, small cross - other chipped stone industry). 


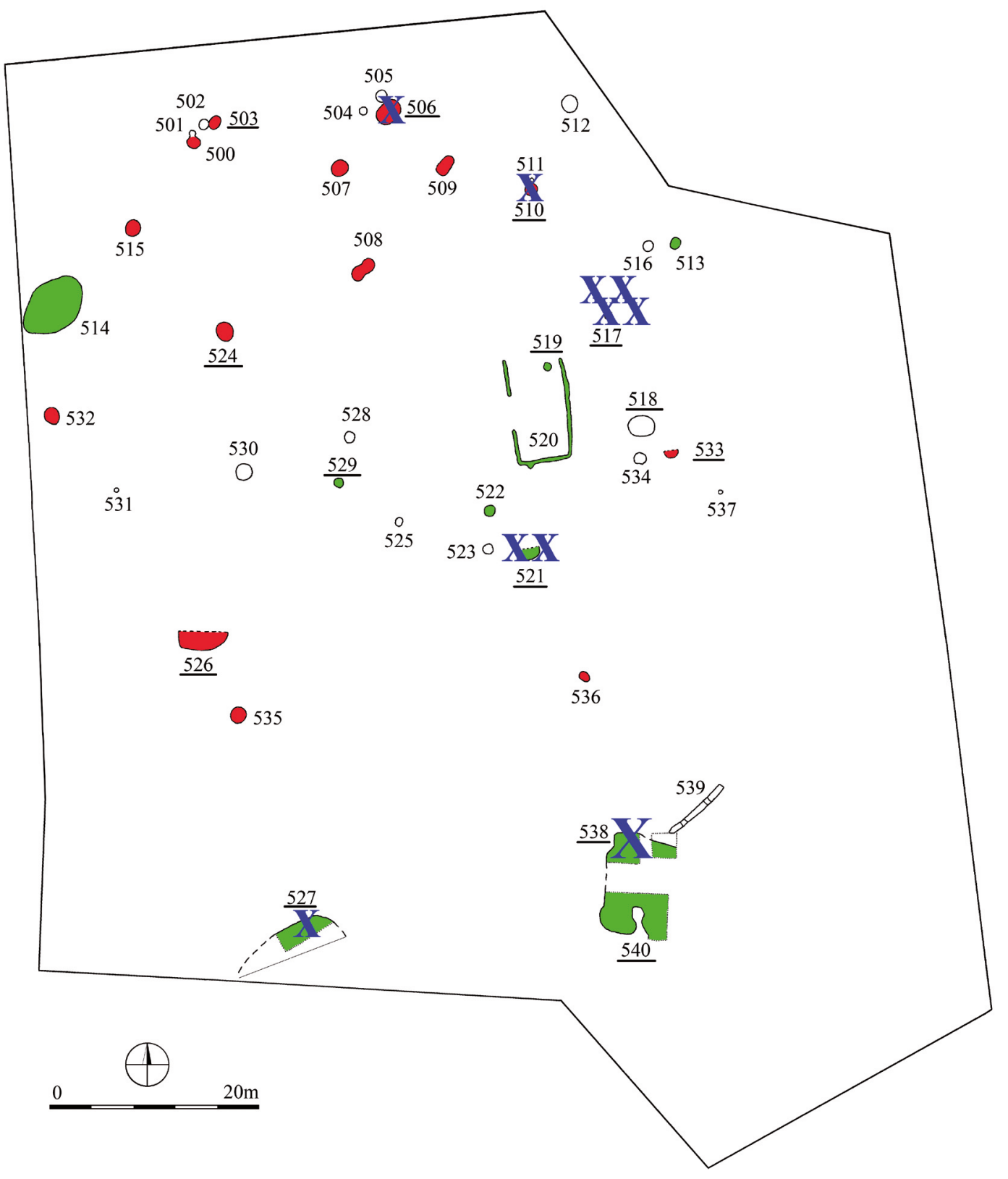

Obr. 8. Distribuce rohovce Stránské skály - varieta světlá v objektech exkavované plochy. Barevné značení viz popis obrázku č. 7.

Fig. 8. Distribution of Stránská skála chert - pale variety in features within the excavated area. Colour marking see in legend to Fig. 7. 


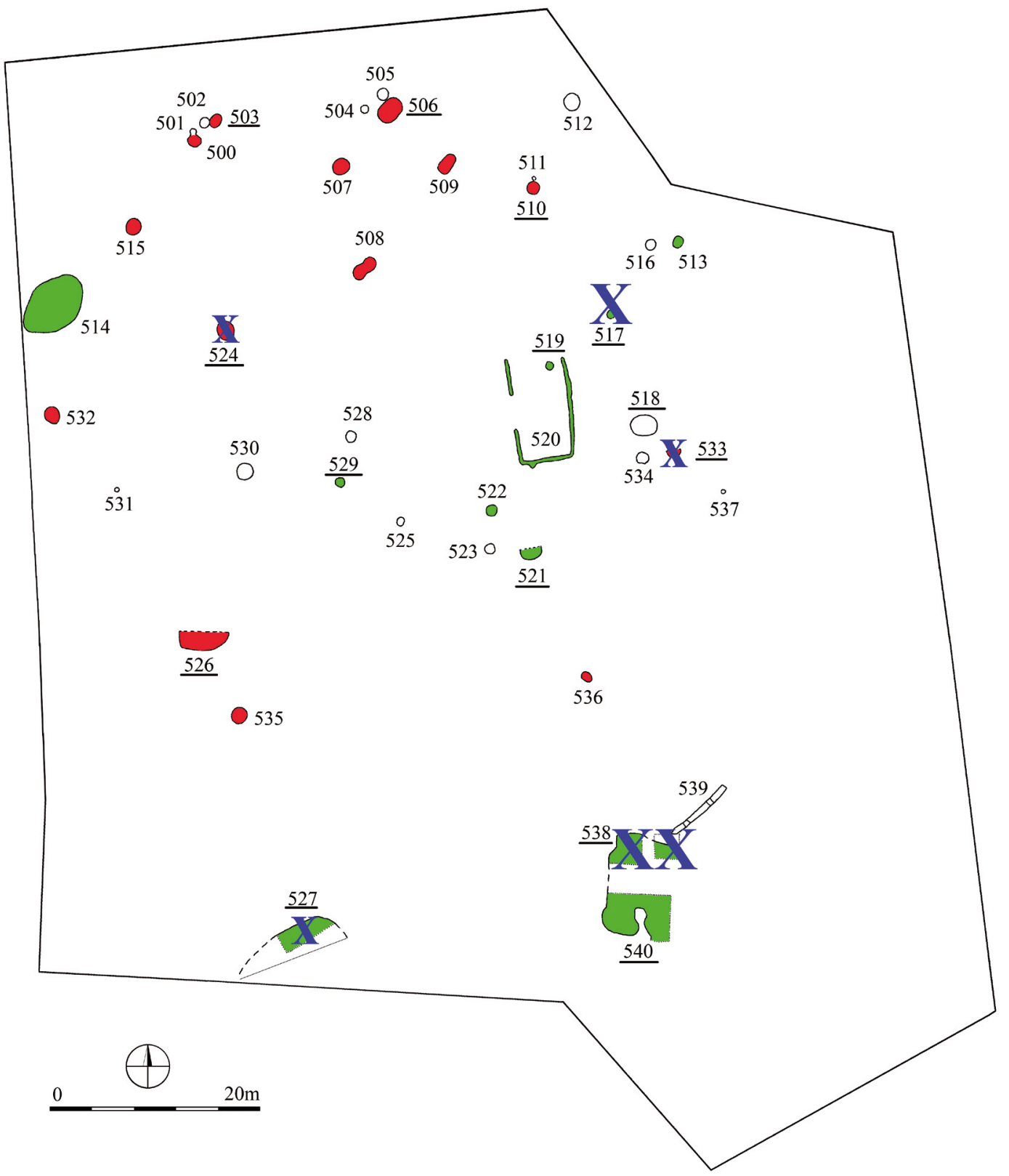

Obr. 9. Distribuce rohovce Stránské skály - varieta světle hnědá v objektech exkavované plochy. Barevné značení viz popis obrázku č. 7.

Fig. 9. Distribution of Stránská skála chert - light brown variety in features within the excavated area. Colour marking see in legend to Fig. 7. 


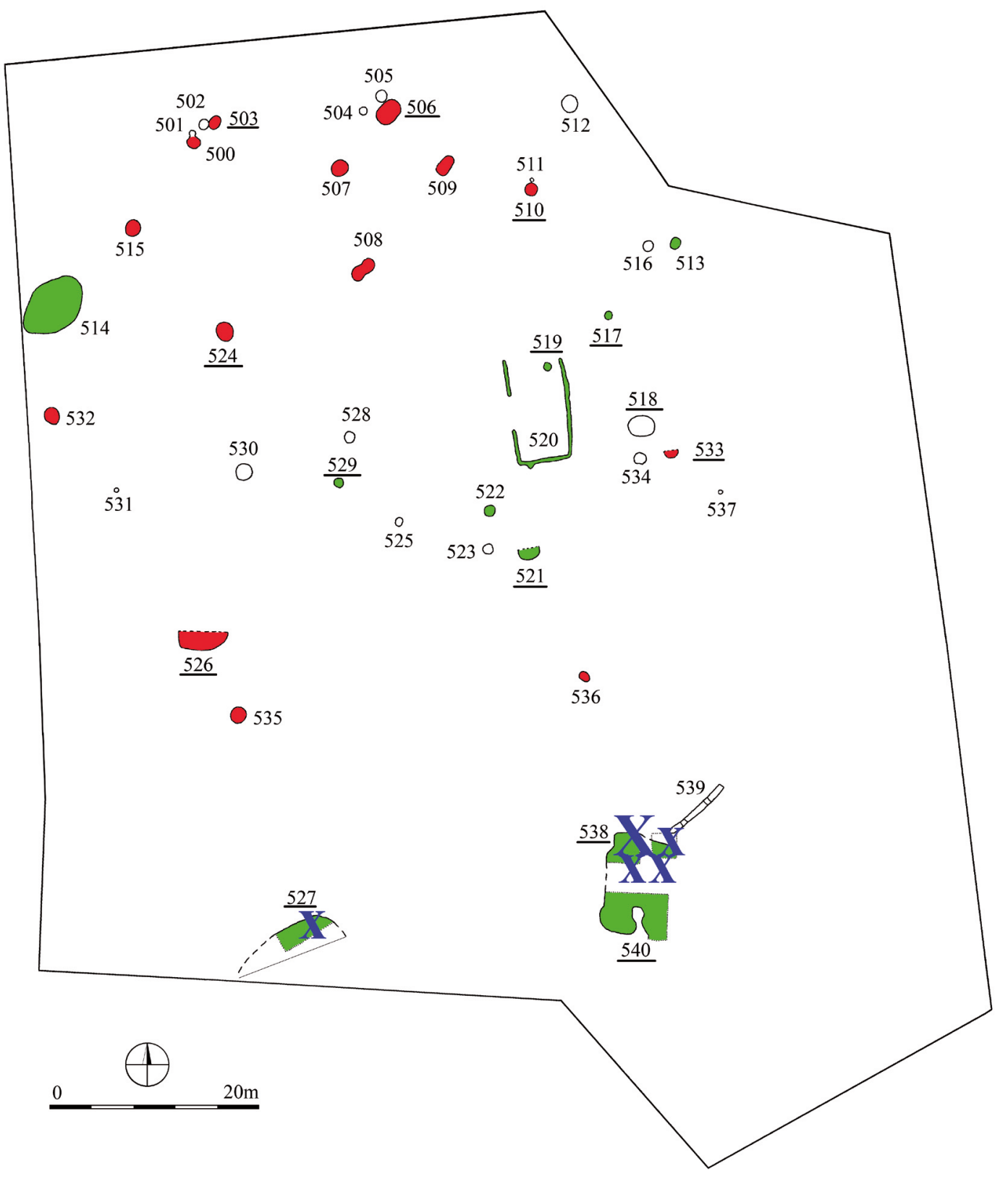

Obr. 10. Distribuce rohovce Stránské skály - varieta šedohnědá v objektech exkavované plochy. Barevné značení viz popis obrázku č. 7.

Fig. 10. Distribution of Stránská skála chert - grey-brown variety in features within the excavated area. Colour marking see in legend to Fig. 7. 


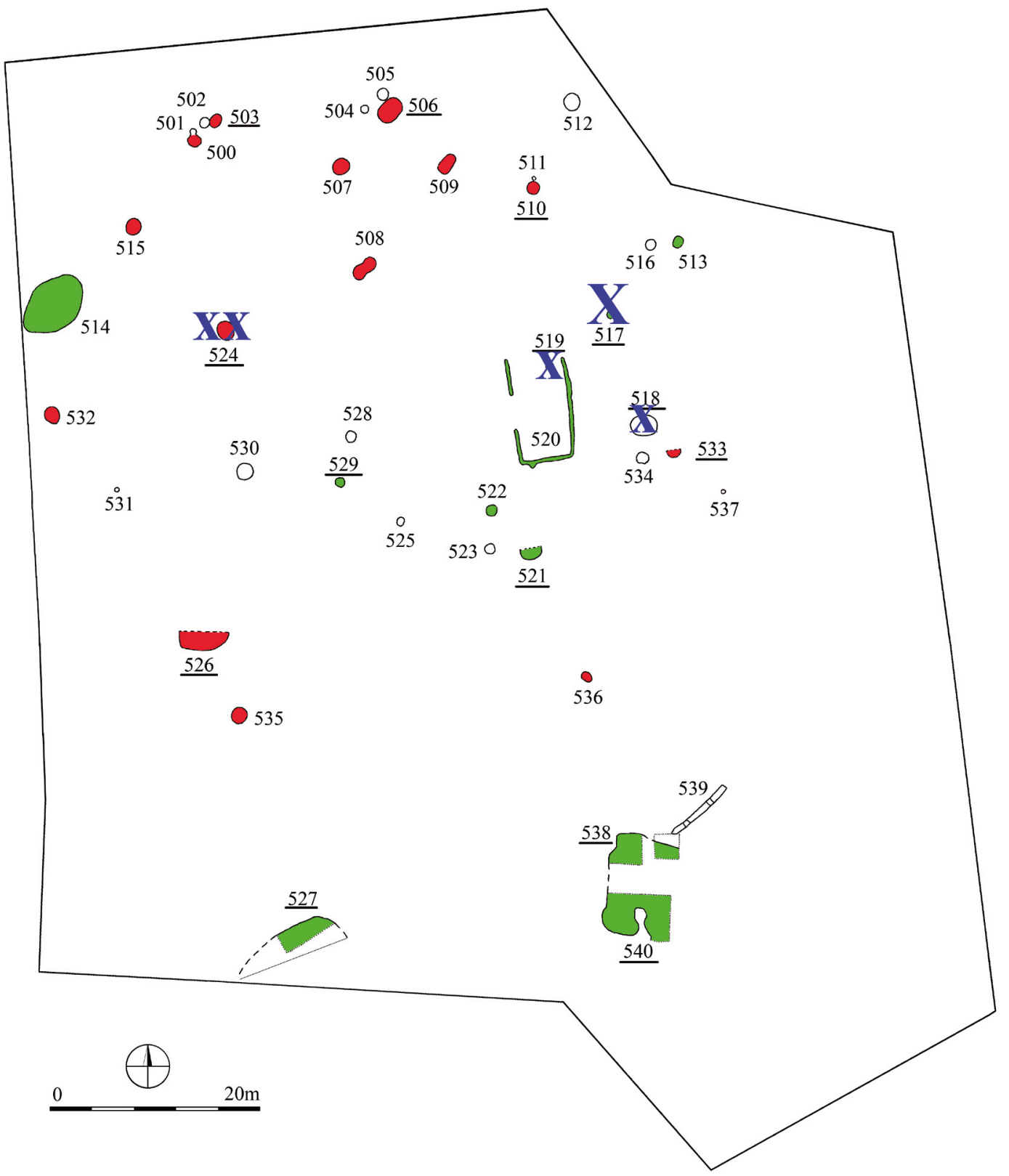

Obr. 11. Distribuce rohovce Stránské skály - varieta zonální v objektech exkavované plochy. Barevné značení viz popis obrázku č. 7.

Fig. 11. Distribution of Stránská skála chert - zonal variety in features within the excavated area. Colour marking see in legend to Fig. 7. 


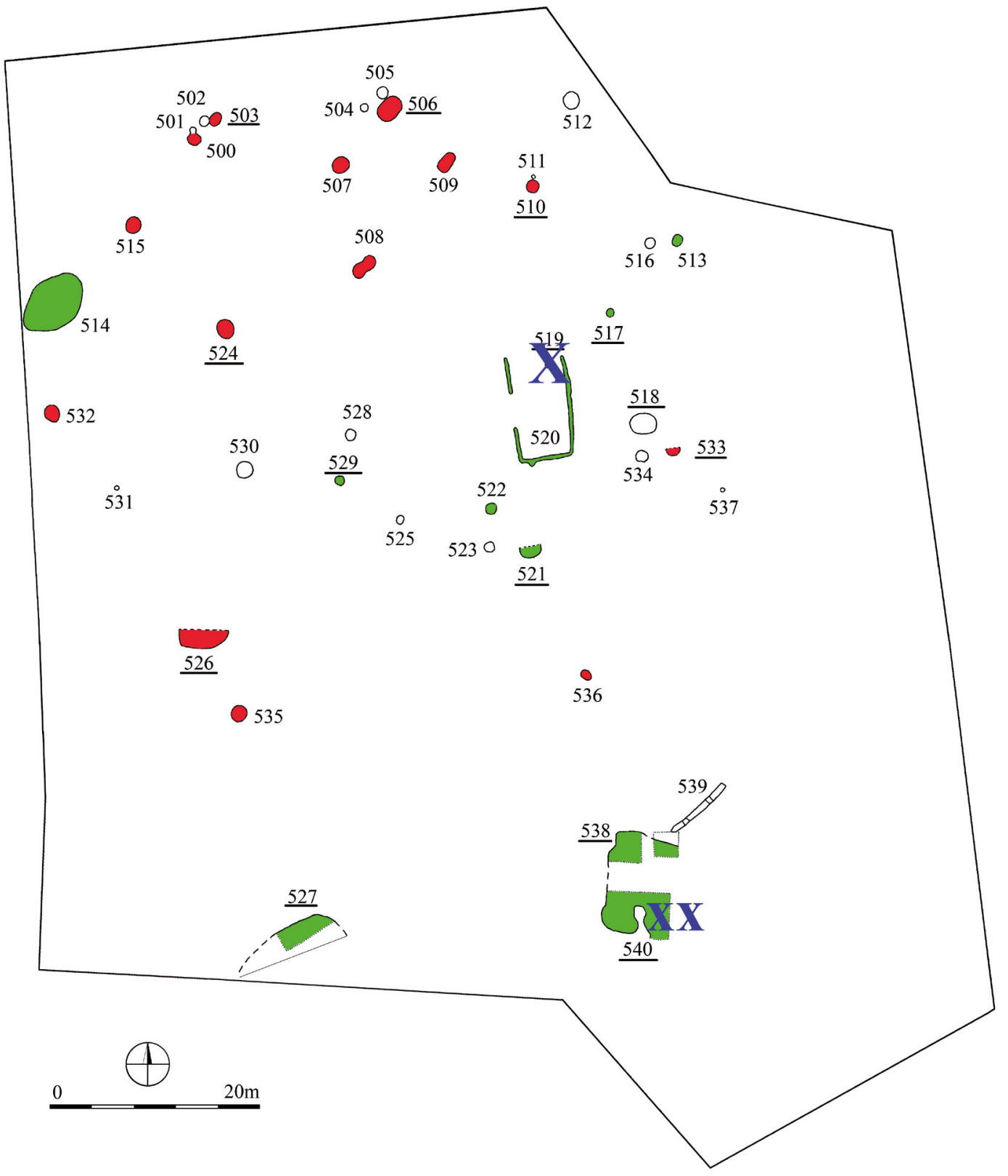

Obr. 12. Distribuce rohovce Krumlovský les v objektech exkavované plochy. Barevné značení viz popis obrázku č. 7. KL I - jádro v objektu 519, KL II - 2 úštěpy v objektu 540 .

Fig. 12. Distribution of Krumlovský les chert in features within the excavated area. Colour marking see in legend to Fig. 7. KL I - core in Feature 519, KL II - 2 flakes in Feature 540. 


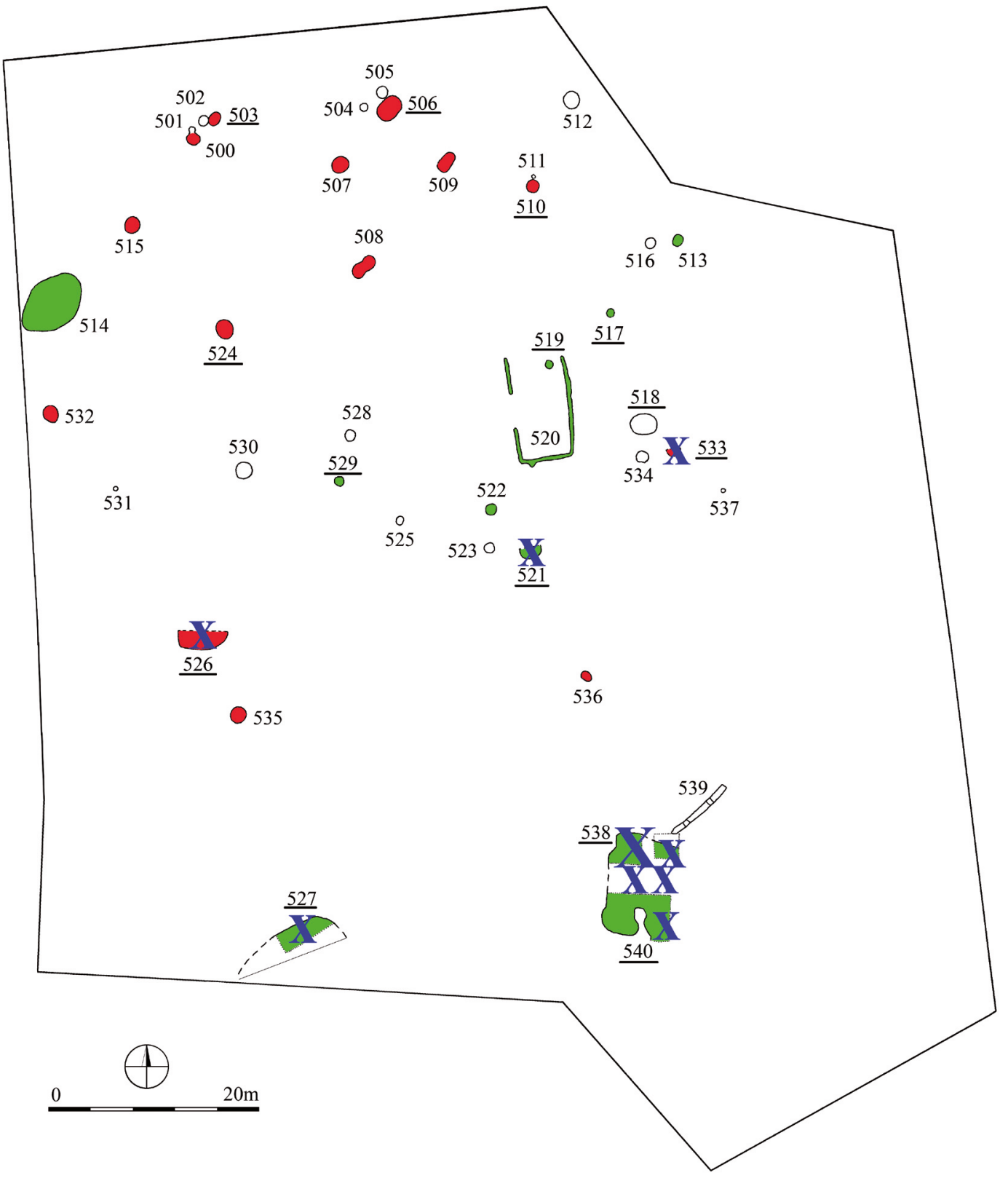

Obr. 13. Distribuce silicitu glacigenních sedimentů (SGS) v objektech exkavované plochy. Barevné značení viz popis obrázku č. 7.

Fig. 13. Distribution of erratic flint in features within the excavated area. Colour marking see in legend to Fig. 7. 
č. 517 (3 jádra a kamenný otloukač) a v objektu č. 538 (4 jádra, zlomek jádra, 2 zlomky suroviny). Kromě nich se dílenský inventář vyskytl v objektu č. 510 (reparační úštěp), v objektu č. 524 (špička jádra, reparační úštěp a 1 zlomek suroviny), v objektu č. 527 (reparační úštěp) a v objektu č. 540 (1 jádro). V objektu č. 519 se kromě toho vyskytlo jádro z rohovce typu KL I, avšak ani objekt, ani celý analyzovaný soubor neobsahuje žádnou debitáž této suroviny. V souboru není prakticky přítomen drobný výrobní odpad, což je však možné přičíst na vrub limitovaným možnostem záchranných výzkumů, kdy systematické plavení nebo prosévání výplně objektů není dosud organizačně únosné, prŕípadně je realizováno jen výběrově nebo vzorkově a zejména s cílem získat organické makrozbytky.

Jádra analyzovaného souboru mají řadu podobných znaků a nelze sledovat žádné technologické rozdíly mezi jádry z různých surovin nebo variet (obrázek č. 14 a 15). Ačkoli z hlediska tvaru jsou spíše oportunisticky utvářená, spojuje je převaha čepelových negativů a nepřítomnost dokladů preparace typu hřebenové úpravy nebo úpravy tvaru těžní plochy. Naopak pravidelně je fasetována podstava, ovšem pouze u čepelové těžby. Také tř̌i zjištěné reparační úštěpy dokládají snahu jádra osvěžovat. Ve dvou případech je reparován tvar úderové hrany (úštěp z boku horní části jádra, drobný úštěp z podstavy), v jednom zalomení na těžní ploše.

Z devíti přítomných jader je jich šest jednopodstavových, jen dvě jsou z hlediska dochovaných negativů na jeho povrchu výhradně úštěpové. Přirozeně nelze zcela opominout možnost, že doklady původní čepelové těžby mohly být sejmuty až následnou těžbou úštěpů. Jedno z jader bylo těženo ze dvou podstav, jeho negativy jsou smíšené, čepelové i úštěpové. Další dvě jádra vykazují změnu orientace těžby, jedno je na obou těžních plochách těženo čepelově, druhé na jedné těžní ploše čepelově a na druhé úštěpově. Přes převahu čepelového sbíjení nebyl autorkou záchranného výzkumu v souboru KPI identifikován žádný měkký otloukač, doložen je pouze výše zmíněný kamenný (tvrdý) otloukač z objektu č. 517. Jádra jsou celkově spíše středních až menších rozměrů, nevyskytují se dlouhá jádra pro výrobu dlouhých silných čepelí, jaké jsou známy ze stránskoskalského depotu. Zajímavé je, že délka čepelové těžní plochy u jader z rohovce Stránské skály je téměř identická, variuje mezi hodnotami 4,0 a 4,6 cm. Nejdelší jádro (resp. nejdelší délka čepelové těžní plochy) je jádro z rohovce KL I, dosahuje $5,6 \mathrm{~cm}$. Nejdelší čepel v souboru je z rohovce Stránské skály variety šedivé (pak 4,9 cm; oba čepelové suporty ze SGS dochované v celé délce jsou této hodnotě také blízké (4,8 a 4,6 cm). Můžeme tedy konstatovat, že rozměry jader a produktů, včetně retušovaných, jsou ve shodě.

Debitáž je z naprosté většiny neretušovaná. Retušováno je pouze šest artefaktů. Nápadný je nepoměr produktů paralelní exploatace vůči počtu čepelových jader. Mezi produkty paralelní exploatace řadím všechnu debitáž s paralelními laterálními hranami a dorzálními negativy, zde se vyskytly dvě čepele a zlomek další, jedna čepelka, jeden čepelovitý úštěp. Úštěp s paralelními negativy z objektu č. 503 se jeví vzhledem $\mathrm{k}$ patinaci a k surovině jako paleolitická intruze. Ostatní kategorie debitáže v souboru činily 34 ks, přičemž nad dekortikační debitáží výrazně převažovaly úštěpy bez kůry (viz tabulka č. 2). Běžně se vyskytly i metrické čepele (k definicím těchto kategorií viz např. Kaňáková 2014, 9). Výskyt debitáže s přirozeným nebo kortikálním bokem zatím není v souborech ŠI kultury nálevkovitých pohárů sledován, v analyzovaném souboru se vyskytuje pravidelně v kategoriích úštěpové debitáže.

Preparace jader se na debitáži projevují minimálně. Ačkoli u jader je doložena prepa- 




517 A74229
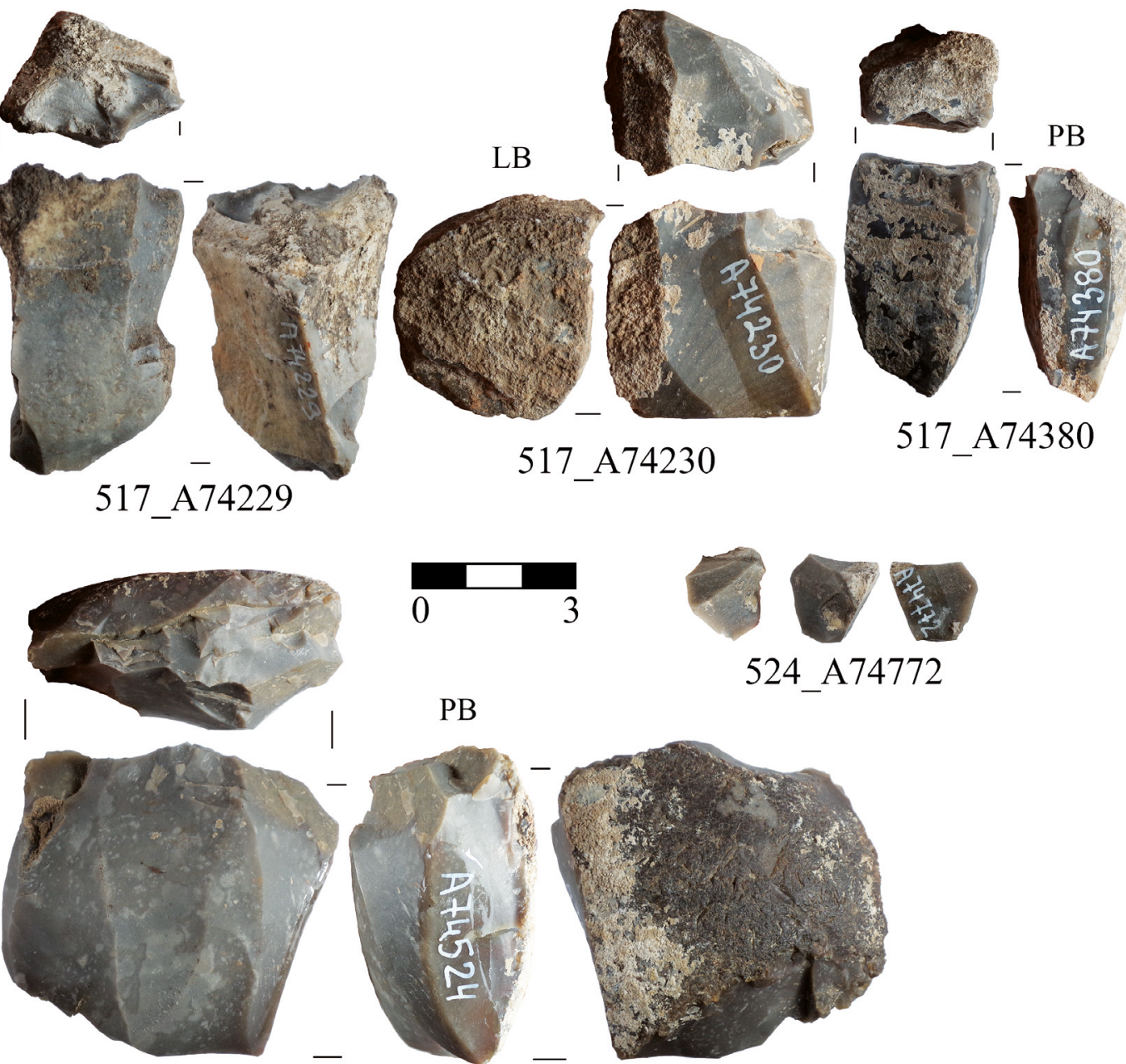

524_A74772

PB

519 A 74524

Obr. 14. Jádra a jejich zlomky souboru Rousínovec - Přední lány.

Fig. 14. Cores and core fragments in the collection from Rousínovec - Přední lány.

race podstavy formou fasetáže, většina $\mathrm{z}$ dochovaných patek debitáže (15 ks) je plochá (tedy tvoří ji jen jeden negativ; 10 ks), v menšině se objeví patka lomená (tvořená dvěma negativy; $3 \mathrm{ks}$ ), případně kortikální ( $2 \mathrm{ks}$ ). Je to dalším dokladem toho, že cílová debitáž, pro jejíž těžbu se podstavy jader preparovaly, aby měly úhel vhodnější pro získání podélné nahodile. Ve smyslu intrasite prostorového debitáže, v souboru chybí. Mezi ŠI z objektů datovaných do JoK a KNP není v tomto ohledu žádný rozdíl.

Retušované nástroje $\mathrm{v}$ souboru tvoří pouze $10,9 \%$ a netvoři žádnou funkčně ucelenou skupinu nebo toolkit. Retušované nástroje se vždy vyskytly v objektech jednotlivě, dá se říci 

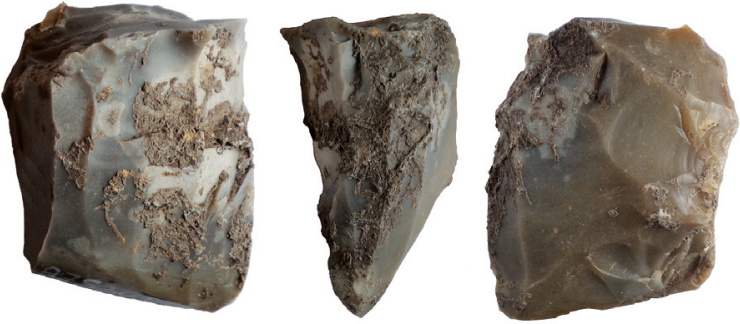

538_A75301

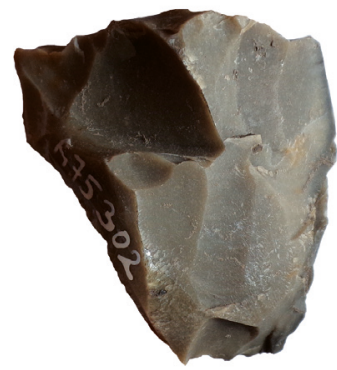

538_A75302

LB
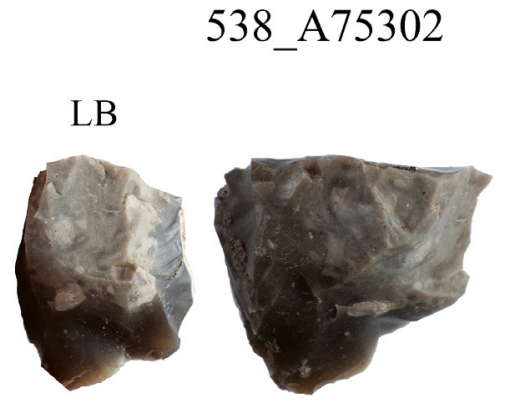

538_A75514
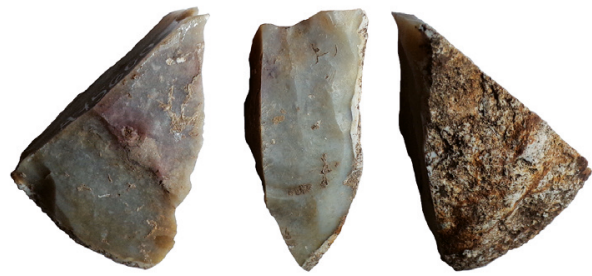

540_A75600

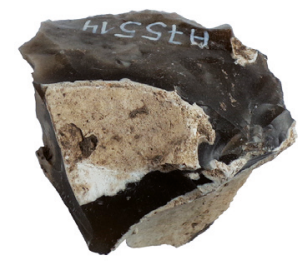

0
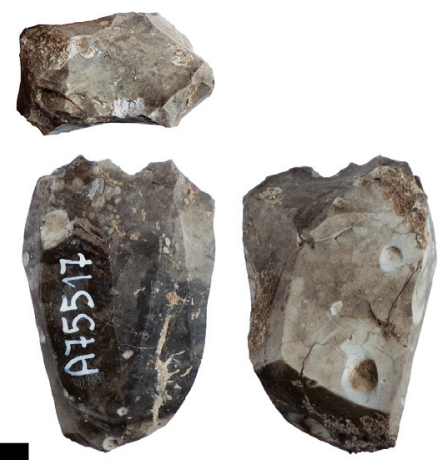

538 A 75517

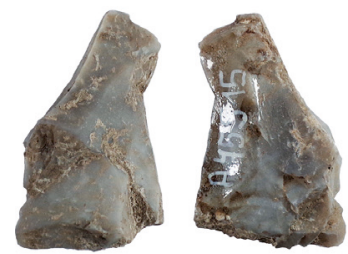

$538 \_$A75515

Obr. 15. Jádra a jejich zlomky souboru Rousínovec - Přední lány.

Fig. 15. Cores and core fragments in the collection from Rousínovec - Přední lány.

uspořádání nevytváří žádnou pracovní zónu, tegorie jemná. Retuše jsou pravidelné, vyskyvyskytují se jak v objektech datovaných do tují se laterální retuše (2 vruby, 1 retušovaná JoK, tak v objektech datovaných do KNP. Ač- čepel), i terminální př́ičné retuše (1 škrabadlo, koli každý z nich je vyroben z odlišného jádra 1 příčná retuš, 1 zoubky). Přehled retušova(odlišné suroviny nebo variety), až na nástroj ných nástrojů souboru viz obrázek č. 16 a taz objektu č. 503 jsou vyrobeny ze suroviny ka- bulka č. 3 . 


\begin{tabular}{|l|c|c|c|c|c|}
\hline $\begin{array}{l}\text { tzv. stádium těžby dle metody } \\
\text { dynamické analýzy }\end{array}$ & neretušované & $\begin{array}{c}\text { z toho } \\
\text { s bokem }\end{array}$ & retušované & $\begin{array}{c}\text { celkem } \\
\text { ks }\end{array}$ & $\begin{array}{c}\text { celkem } \\
\%\end{array}$ \\
\hline zlomky suroviny & 3 & & & 3 & 5,50 \\
\hline jádra & 9 & & & 9 & 16,40 \\
\hline zlomky jader & 2 & & & 2 & 3,60 \\
\hline otloukač & 1 & & & 1 & 1,80 \\
\hline reparační úštěpy & 3 & & & 3 & 5,50 \\
\hline kortikální úštěpy & 2 & & & 2 & 3,60 \\
\hline semikortikální úššěpy vč. zlomků & 5 & 1 & 1 & 6 & 10,90 \\
\hline úštěpy bez kưry vč. zlomků & 13 & 3 & 2 & 15 & 27,30 \\
\hline metrické čepele vč. zlomků & 5 & 2 & & 5 & 9,10 \\
\hline čepelovitý úštěp & 1 & & & 1 & 1,80 \\
\hline čepele a čepelky vč. zlomků & 4 & & 3 & 7 & 12,70 \\
\hline pravděpodobné intruze & 1 & & & 1 & 1,80 \\
\hline celkem & $\mathbf{4 9}$ & $-\mathbf{6}$ & $\mathbf{6}$ & $\mathbf{5 5}$ & $\mathbf{1 0 0}$ \\
\hline
\end{tabular}

Tab. 2. Přehled základní kategorií dle metody dynamické analýzy.

Tab. 2. An overview of main categories based on the method of dynamic analysis.

\begin{tabular}{|l|c|c|c|c|c|}
\hline objekt & datace dle keramiky & funkce objektu & surovina & suport & retušovaný nástroj \\
\hline 503 & KNP & sídlištní jáma & StS šedivá & L & příčná retuš \\
\hline 517 & JoK & zásobní jáma & StS světlá & SÚ & vrub \\
\hline 521 & JoK & sídlištní jáma & SGS & L & vrub \\
\hline 524 & KNP & sídlištní jáma & StS zonální & BÚ & zoubky \\
\hline 526 & KNP & sídlištní jáma & SGS & L & retušovaná čepel \\
\hline 533 & KNP & sídlištní jáma & SGS & Bú & škrabadlo \\
\hline
\end{tabular}

Tab. 3. Přehled retušovaných nástrojů podle objektů, datace dle typologie keramiky, suroviny a suportu.

Tab. 3. An overview of retouched tools according to features, dating on the basis of ceramic typology, raw material and supports. 



526_A74921

Obr. 16. Retušované nástroje souboru Rousínovec - Přední lány.

Fig. 16. Retouched tools in the collection from Rousínovec - Přední lány.

\section{Závěr}

Na základě zjištěných dat můžeme znovu konfrontovat otázku formování archeologického obrazu lokality. Štípaná industrie přriřazená datováním na základě typologie keramiky $\mathrm{k}$ jordanovské kultuře zahrnuje zejména obsah zásobních jam - objektů č. 517, 519 a 529, u nichž lze předpokládat depozici až po zániku zásobní funkce jámy, jak o tom svědčí i další analyzované znaky. Dále zahrnuje obsah stavebních jam - objektů č. 527 a 538 a sídlištních jam - objektů č. 521 a 540. O štípané industrii jordanovské kultury bylo dosud $\mathrm{v}$ našem prostředí známo jen velmi málo. Nyní můžeme konstatovat, že v technologii běžné sídlištní výroby se příliš neliší od technologie KNP, preferuje čepelovou těžbu poměrně krátkých jader, které preparuje zejména fasetáží podstavy. V závislosti na kvalitě suroviny využívá změny orientace jádra, stejně jako přechod z čepelové exploatace na úštěpové dotěžení jádra. Patky v místě zanechané debitáže jsou obvykle ploché. Lze konstatovat jistou tendenci k jemným hmotám surovin, která je v kontrastu k preferencím zjištěným v části souboru spojené s kontextem KNP.

Artefakty netvoří žádnou průkaznou pracovní nebo funkční zónu a jejich výskyt v sídlištních objektech má spíše charakter depozice sídlištního odpadu. V tomto kontextu je také zřejmě signifikantní, že z i tak nevelkého počtu neretušované debitáže (35 ks) je celá třetina fragmentární (12ks). Retušovaná debitáž je na sídlištní poměry také mimořádně málo početná (6ks). Přitom je soubor surovinově i typologicky poměrně homogenní.

Můžeme tedy nastínit, že se zde v obou fázích osídlení realizovala nepř́iliš intenzivní, ale 
technologicky uniformní výroba ŠI převážně z donesených jader stránskoskalského rohovce s minimálními doklady preparace, a že charakter souboru je prost atraktivních produktů, jako jsou dlouhé čepele a projektily. Je zjevné, že jak veškerá cílová produkce, tak většina na sídlišti používaných nástrojů byla přesunuta jinam, bud' do jiné zóny sídlišstě, která nebyla exkavována, nebo pravděpodobněji na jiná sídliště. Zachované depozice mají výrazně odpadní charakter jak z hlediska stavu dochování, tak z hlediska distribuce a nízké prostorové souvislosti jader a debitáže z jednotlivých surovin a variet. Jisté doklady lokalizace výrobních míst můžeme sledovat pouze v objektech č. 524 a 538 . Výskyt ŠI v zásobních jamách datovaných dle keramiky do kontextu JoK není funkčně souvislý s funkč- ním užíváním jam a k depozici došlo později, snad ve fázi osídlení KNP, o čemž by svědčila analyzovaná spektra variet a surovin.

Podrobná analýza tohoto souboru s komplikovanou depoziční historií přes uvedená zjištění ilustruje operování s kamennou surovinou dosud málo prizmatem ŠI sledované populace časného a staršího eneolitu. Ačkoli zejména pro civilizaci KNP je kámen a jeho štípání již velmi významné i v symbolické rovině, což se zejména v severozápadní oblasti rozšsiřrení KNP odráží v rozvoji produkce reprezentativních bojovnických atributů (Apel 2001; Migal 1997), nárůstu důlních aktivit (Lech 1997) i budování megalitů (Müller 2011), sídlišstě v poloze Rousínovec - Přední lány nám ukazuje obrázek výsostně praktický a užitkový.

1) Soubor byl ponechán v původním stavu. Vzhledem k charakteru souboru nebyla aplikována traseologická metoda, a z toho důvodu soubor nebyl před analýzou zbaven sintru ani přelakovaných evidenčních čísel. Zbytečně aplikovaná očista by mohla zničit potencionálně dochovaná mikrorezidua a jiná data. Umístování evidenčních čísel přímo na artefakty ŠI není příliš vhodný postup, protože silně zakrývá některé charakteristiky ploch a hran, jakými jsou opotřebení, otěry, lesky, ale i drobnou retuš. Omezuje také kresebnou a zejména fotografickou dokumentaci. V jednom případě došlo dokonce ke slepení dvou artefaktů.

\section{Literatura}

Apel, J. 2001: Dagger, Knowledge \& Power. The Social Aspects of Flint-Dagger Technology in Scandinavia. 2350-1500 cal BC. Coast to coast-book 3. Uppsala. Břiza, S. - Ulahel, P. 2015: Úvalno (okr. Bruntál). Přehled výzkumů 56, číslo 1, 172-174.

Čižmář, M. - Geisler, M. - Horálková, P. 1986: Rousínov - Rousínovec, trat Přední lány. Nálezová zpráva č. 1613/86 Archeologického ústavu AV ČR v Brně.

Domańska, L. 2013: Krzemieniarstwo horyzontu klasycznowióreckiego kultury pucharów lejkowatych na Kujawach. Łódź.

Gijn, A. van 2010: Flint in Focus. Lithic Biographies in the Neolithic and Bronze Age. Leiden.

Hladiková, L. 2004: Štípaná industrie starší doby bronzové. Sborník prací FF MU, řada archeologická: M8-9, roč. 2003-2004. Brno, 65-87.
Högberg, A. 2016: Microdenticulates of the Funnel beaker Culture. Lithic attribute analysis, use-wear analysis, and contextual analysis. Acta Archaeologica.

Iversen, R. 2014: Transformation of Neolithic Societies: An East Danish perspective on the 3rd millennium BC. Copenhagen.

Kaňáková, L. 2014: Unikátní soubor štípané industrie doby bronzové z polohy Blučina - Cezavy. Památky archeologické 105, 5-46.

Kopacz, J. - Šebela, L. 2010: Lithic Chipped Industry of the Jevišovice Culture in Moravia. An Introductory study. Přehled výzkumů 51, číslo 1-2, 69-96.

Lech, J. 1997: Remarks on Prehistoric Flint Mining and Flint Supply in European Archaeology. In: Ramos-Millán, A. - Bustillo, A. (eds.) 1997: Siliceous Rocks and Culture. Granada, 611-637.

Migal, W. 1997: Selected aspects of specialization in mining and flint knapping. In: Man and flint. 
Proceedings of the 7th International Flint Symposium, Warszawa-Ostrowiec Świętokrzyski, september 1995, 99-101.

Mikulková, B. 2006: Rousínov - Rousínovec, logistické centrum HET, č. alce 172/06. Nálezová zpráva č. 13/7 Ústavu archeologické památkové péče Brno.

Mikulková, B. 2010: Rousínov (K.Ú. Rousínovec, okr. Vyškov). Přehled výzkumů 51, 337-338.

Müller, J. 2011: Megaliths and Funnel Beakers: Societies in Change 4100 - 2700 BC. Amsterdam.

Oliva, M. 2017: Těžba rohovce z doby kultury nálevkovitých pohárů v Krumlovském lese (jižní Morava). Archeologické rozhledy LXIX, 3-22.

Popelka, M. 2008: Štípaná industrie z Úholiček, okr. Praha - západ. Archeologické rozhledy LX, 298-302.

Přichystal, A. 2009: Kamenné suroviny v pravěku východní části střední Evropy. Brno.

Šebela, L. a kol. 2007: Hlinsko: výšinná osada lidu badenské kultury. Spisy Archeologického ústavu AV ČR Brno. Brno.
Šikulová, V. - Zápotocký, M. 2010: Raně eneolitický měděný pektorál z vrchu Kotouče u Štramberka. Archeologické rozhledy LXII, 395-428.

Šmíd, M. - Dreslerová, G. - Přichystal, A. 2010: Hrad u Bílovic. Eneolitické hradisko na Prostějovsku. Pravěk Supplementum 21, Brno, Ústav archeologické památkové péče Brno.

Šmíd, M. - Přichystal, A. 2015: Eneolitická hradiska na Prostějovsku. Ohrozim - Čubernice a ProstějovČechovice - Čechovsko. Pravěk, Supplementum 29, Brno, Ústav archeologické památkové péče Brno.

Vencl, S. 1985: Chipped Industry. In: Pleslová Štiková, E. 1985: Makotřasy: A TRB Site in Bohemia. Fontes Archeologici Pragenses 17, Praha, 165-174.

Vencl, S. 2012: Štípaná industrie ze sídliště KNP ve Vikleticích, okr. Chomutov. Sborník Drahomíru Kouteckému, 309-312.

Vencl, S. 2014: Štípaná industrie ze sídliště pozdní fáze KNP v Brozanech nad Ohří, okr. Litoměřice. Archeologie ve středních Čechách 18, 57-63. 


\section{Collection of Early and Old Eneolithic chipped stone industry from the settlement of Rousínovec - Přední lány}

The evaluated assemblage of finds comes from an archaeological rescue excavation at Přední lány site in cadastral district of Rousínovec village (for localisation of the site see Figure 1), where a settlement of Jordanów Culture and another part of an already earlier explored settlement of Funnel Beaker Culture (FBC) were situated (Čižmár - Geisler - Horálková 1986).

It is a locality with settlement sites of two chronologically closely related cultures. The dating of individual features in the excavation report was based on cultural affiliation of pottery contained in their backfill. The plan of the area uncovered in 2006 (Figure 2) distinguishes in colour the features which are dated to the Jordanów Culture or Funnel Beaker Culture on the basis of typology of ceramic finds. Features containing chipped stone industry are clearly described in Table No. 1.

Chipped stone industry never occurs in storage pits of FBC (and in pits with undated material) but we can find it in all storage pits of Jordanów Culture. Regarding the function, there is no reason for an intact presence of chipped stone industry in storage features and the determination of individual finds does not indicate this phenomenon, either (cores, hammerstone, decortication debitage, fragmented tools and debitage). Therefore we can suppose that storage pits of Jordanów Culture contain chipped stone industry which landed here secondarily, most probably at the time when the area was inhabited by people of FBC. Nevertheless, functional association of chipped stone industry in ordinary settlement pits and clay pits with any of the two settlement horizons is not so conclusive, because these pits may have already been backfilled accidentally during everyday life of the inhabitants.

The collection contains 55 artefacts from fourteen features in total. The assemblage appears homogeneous, both in the raw materials and in the technology used. Therefore we can either attribute the collection as a whole to one of the cultures inhabiting the area, or we must conclude that chipped stone industry of both these cultures is almost the same. Dominant raw material in the assemblage is represented by colourful varieties of cherts from Stránská skála (41 pcs, $75 \%$ ). The varieties were already defined by A. Přichystal in 1982 (for a well-arranged overview see Přichystal 2009, 65 and 67, and Photo 47 on p. 274). I am using a combination of colour spectrum and quality spectrum (Hladiková 2004, 69). An overview of the identified varieties is shown in Figure No. 3. The distance as the crow flies between Stránská skála and the locality in question is not long, only about $15 \mathrm{~km}$. The collection also contains a minor amount of raw materials from more distant sources. Both varieties of the Krumlovský les chert (3 pcs, $5 \%$ ) may originate not only from the eponymous area of Krumlovský les (Krumlov Forest), where mining activity was recently also identified for the time of $\mathrm{FBC}$ (Oliva 2017), but hypothetically also from Stránská skála and its north-eastern neighbourhood (Prichystal $2009,72)$. The occurrence of flint from northern regions is recorded by me in general as erratic flint (SGS), with the reservation that several pieces, with regard to their distinctly darker nut-brown colour, might originally come from the Polish Jurassic Highland. The occurrence of this raw material in erratic sediments was accentuated by A. Přichystal (Prichystal 2009, 48).

The graph (Figure No. 5) clearly shows the difference between chipped stone industry from features of Jordanów Culture and FBC. Finds from Jordanów features exhibit an evident preference for fine-grained materials, whereas the finds from features of FBC rather preferred quality. When we would relativise the cultural affiliation of chipped stone industry discovered in storage pits of Jordanów Culture, namely in features No. 517, 519 and 529, then this picture would be even more pronounced (Figure No. 6). For the identification of possible production zones, cores from individual raw materials are highlighted (Figures 7 to 13). From the results follows that the deposition of chipped stone industry in storage features of Jordanów Culture is culturally and functionally not original, but it was caused by accidental processes. The raw material of cores is in no 
accordance with the raw material of debitage in the feature. Cores landed in the feature in the same accidental manner as the other debitage and therefore they do not give evidence of any production zone. In the settlement pit of FBC No. 524, on the other hand, we can identify such a connection between a core and debitage.

With regard to basic dynamic analysis, the collection contains an increased amount of cores and other associated workshop inventory, such as raw material fragments, a hammerstone and rejuvenation flakes. Cortical debitage is in minority in comparison to cores, so that the major part of primary decortication of nodules must have been performed elsewhere, or this processing zone was not captured by the excavations. The cores exhibit many similar attributes and we cannot observe any technological differences between cores from various raw materials or varieties (Figures No. 14 and 15). Their formation was rather opportunistic, and the dominant features are blade negatives and the absent evidence of crested preparation or shape adjustment of the flaking surface. The striking platform is evenly faceted only in blade reduction. Three identified rejuvenation flakes indicate the effort to rejuvenate the cores. The cores are generally rather mid-sized to small-sized, long cores for production of long thick blades are absent. The dimensions of cores and products, inclusive of retouched tools, are in accordance. Although the cores exhibit preparation of the striking platform by faceting, most of the preserved butts in debitage (15 pcs) are flat (10 pcs). There is a striking disproportion between products of parallel reduction and the number of blade cores. The decortication debitage was distinctly outnumbered by non-cortical flakes (see Table No. 2). Metrical blades also were common (for definition of these categories see e.g. Kañáková $2014,9)$. The vast majority of debitage is non-retouched. Only six artefacts are retouched. Retouched tools represent only $10.9 \%$ of the whole assemblage of finds and they do not form any processing zone - they occur both in features of Jordanów Culture and in those of FBC. Retouches are regular, among them are lateral retouches $(2$ notches, 1 retouched blade) as well as terminal transversal retouches (1 end-scraper, 1 transversal retouch, 1 denticulate). For an overview of retouched tools from the collection see Figure No. 16 and Table No. 3.

Considering the information above, we can suppose that in both settlement phases existed a not very intensive but technologically uniform production of chipped stone industry, prevalently from chert cores imported from Stránská skála with minimal evidence of preparation. Any products attractive for distribution, such as long blades and projectiles, are missing. It is evident that both the entire final production and most of the tools used in the settlement were transferred to some other place. The preserved depositions are maximally sorted and exhibit all attributes of refuse, with regard to both their state of preservation and the distribution and weak spatial relation between cores and debitage from individual raw materials and varieties. The occurrence of chipped stone industry in storage pits dated according to pottery to the context of Jordanów Culture is in no functional relation to the everyday use during functional life of these pits. The finds were deposited here later, maybe during the settlement phase of FBC, which is indicated by the analysed spectrums of varieties and raw materials.

\section{Mgr. Ludmila Hladíková-Kaňáková, Ph.D.}

- Ústav archeologie a muzeologie,

Filozofická fakulta, Masarykova univerzita,

A. Nováka 1, 60200 Brno, Česká republika

ludmila@kanakova.cz 